\title{
The Role of External Auditor in Protecting the Financial Information Listed in the Financial Statements in the Jordanian Industrial Companies
}

\author{
Firas A. N. Al-Dalabih \\ Irbid National University, Jordan
}

\begin{abstract}
This study aims to know the role of external auditor in protecting the financial information listed in the financial statements in the Jordanian industrial companies. The sample of this study consisted of 70 auditors who work for Jordanian industrial companies, whereas a questionnaire survey was designed and distributed to them. A total of 68 questionnaires were received that are valid for statistical analysis accounting for $97 \%$ of the overall distributed questionnaires; and the questionnaires have been analyzed using SPSS statistical software. The results of the study revealed that the external auditor uses the information technology in examining the financial information listed in the financial statements. Also, it was found that the external auditor is keen to ensure the credibility of the financial statements of the company. The study recommended the external auditor in the Jordanian industrial companies to be more interested in updating the company's electronic financial system.
\end{abstract}

Keywords: external auditor, financial statements, Jordanian industrial companies

\section{Introduction}

Auditors have been responsible for detecting fraud in many stages. Initially, auditors were responsible for detecting fraud, as one of the main objectives of the review process. However, nowadays the auditors' responsibility is limited to examining the financial statements and giving reasonable assurance, not at all, about the extent to which the financial statements are free of fraud and that they reflect honestly and fairly the financial position of the company (Alarbeed, Alothman, \& Assee, 2014).

The external audit represents the audits operations for the parties outside of the entity under auditing, by experts specialized independent of entity under auditing, or its staff or officers, called the external auditors. These auditors are qualified and independent, and the external auditor performs the audit in accordance with the international auditing standards (Lotfii, 2005).

Information technology plays an important and influential role in the external audit process, as traditional methods and procedures no longer fit the audit process in the context of electronic data processing and the era of informatics, in which electronic accounting systems provide information in a large and fast degree, and with high accuracy and efficiency than before (Zghoot, 2016).

According to Kasswna (2012), information technology has become a reality that should be recognized in these days, due to rapid changes and developments at all levels.

Firas A. N. Al-Dalabih, Assistant Professor, Department of Accounting Information System, Irbid National University. Email: nabudalbouh@gmail.com. 


\section{Statement of Problem}

As a result of the spread of the use of electronic technologies and computerized applications and the great development in most economic sectors, the auditors have high responsibility to provide their services at the highest level of quality according to the technology development, and this creates challenges in auditing profession due to the level of keeping pace with technological developments.

Based on the above, this study attempts to find answers to the following questions:

(1) Does the external auditor use the information technology to examine the financial information listed in the financial statements?

(2) To what extent is the external auditor keen to ensure the credibility of the financial statements of the company?

\section{Importance of the Study}

The external auditing plays a significant role in controling the financial data through external auditor works; this is in light of the enjoyment of the external auditor's independence and impartiality of opinion.

The importance of this study is determined by the importance of providing accurate information with high credibility for all the financial statement's beneficiaries in order to make right financial decisions.

\section{Study Objectives}

This research aims to know the role of external auditor in protecting the financial information listed in the financial statements in the Jordanian industrial companies, through achieving the following objectives:

(1) Identify the extent to which the external auditor is using the information technology to examine the financial information listed in the financial statements;

(2) To determine the extent to which external auditor is keen to ensure the credibility of the financial statements of the company.

\section{Hypotheses of the Study}

We can develop the following hypotheses:

Ha1: The external auditor uses the information technology to examine the financial information listed in the financial statements.

Ha2: The external auditor is keen to ensure the credibility of the financial statements of the company.

\section{Literature Review}

Kassem and Higson (2016) conducted a study aiming to determine the role of external auditors in corporate corruption, besides determining the implications for external audit regulators.

Depending on the theoretical approach, the paper discussed the responsibilities of external auditors in relation to corporate corruption and the impact of corruption on the financial statements by providing evidence from prior literature. In addition, the paper examined the impact that corporate corruption might have on the audit profession by providing evidence from actual corruption cases.

The results revealed that external auditors are responsible for detecting material misstatements arising from corruption that would have a material impact on the financial statements.

DiGabriele and Ojo (2014) highlighted the dual roles of external auditors and its impact on the objectivity and independence, in addition to examining whether it is suitable for the external auditors to incorporate internal auditor's responsibility or not. 
The methodology of the study depends on the theoretical approach by discussing the key attributes in the performance of external and internal audits, principles relating to the supervisory expectations relevant to the internal audit function, changing roles of internal and external auditors and post-Enron consequences, limitation on the use of internal audit roles. In addition, the paper discussed the impact of internal auditor compensation on external auditor's objectivity and independence.

The results revealed that the dual roles of external auditors have a significant impact on the objectivity and independence, and it adds high value to the organizations.

Tawfeq and Jabali (2014) aimed in their study to know the relationship between the information systems of accounting, auditing, and how to provide reliable information to characterize the service auditor.

To achieve the goals of the study, it depends on the theoretical approach by reviewing the previous studies and discussing the concept of accounting information systems and their components, the importance of the review in light of computerized information systems, in addition to discussing the auditor function in light of accounting information systems.

The results illustrated that there is a relationship between the information systems of accounting and auditing. It was found also that most of the accountants do not know enough about computer operations, and do not have enogh understanding about the automatic and manual accounting system.

Alarbeed et al. (2014) investigated the role of governance rules in improving the auditor's ability to detect fraud in the financial statements in Syria.

The research sample consists of the total auditors who are accredited by the Syrian Exchange and Securities Commission, and their number was 31 auditors in 2013. A questionnaire has been distributed to the sample of the study, and the number of returned questionnaires was 22 , which represents $70.97 \%$ of the total distributed questionnaires.

The results showed a positive significant role of governance rules in improving the auditor's ability to detect fraud in the financial statements.

Almeshal (2014) studied the role of auditor independence in achieving governance requirement and its impact on accounting information in Palestine.

To achieve the purpose of study, a questionnaire had been developed and distributed to the sample of the study which consists of 79 members who work in audit firms.

The results investigated a positive significant role for the auditor independence in achieving governance requirement. Also, it was found that there is a positive significant role for the auditor independence in enhancing the creditability of accounting information.

Ahmed and Shil (2013) studied the role of internal auditors in protecting existing and prospective investors in Bangladesh.

To achieve the goal of study, four different survey questionnaires had been developed and distributed for internal auditors, finance and accounting department executives, investors and board of directors in 100 companies, and the number of the investors was 500, but the returned questionnaires were 400 .

The results revealed that there is a strong and significant relationship between independence of internal auditors and independence of finance and accounts department. Furthermore, the results revealed a strong and significant relationship between the independence of finance and accounting departments and corporate governance. 
Salem (2012) examined the auditor's responsibility to detect fraud on financial statements.

To achieve the aim of the study, it depends on the theoretical methodology by reviewing the previous related researches.

The study found that the amount of fraud that is detected appears to have declined because of the use of more advanced technology. Also, the result found that auditors have limited legal expertise and they need special training that identifies all illegal activities.

Matar (2012) investigated the impact of legal responsibility of external auditors on auditing quality and investment level in Kuwait.

To achieve the aim of study, a questionnaire has been distributed to the sample of the study which consisted of 105 members who use the financial reports in brokerage firms, investment firms, commercial banks, and stock exchange. Another questionnaire has been distributed to the auditors who work in 50 local auditing firms and international auditing firms, and their number was 184, where the number of the retuned questionnaires was 98 .

The results of the users' questionnaire illustrated that trust in financial information will be enhanced through increasing auditor liability. Also, it was found that the users need auditing services, and they require auditors to provide collateral for their investment process in order to increase their investment level.

On the other hand, the results of auditors' questionnaire revealed that the auditors do not agree that their liability should be increased since this will make auditing services more costly. Also, it was found that auditors believe that the existence of legal liability rules will make financial statement users more trustful in financial information.

Jovković, Ljubisavljević, and Obradović (2012) highlighted the role, importance, and objectives of the external audit in banks in Serbia.

To achieve the purpose of study, survey questionnaire had been developed and distributed to the sample of the study which consists of the employees who work in 28 banks operating in Serbia.

The results revealed that the primary service that auditors provide to banks is the audit of financial statements, then the review of other financial information and the assessment of the risk facing the bank. The results also showed that banks rarely use the services of tax calculation, non-financial performance measurement, and traditional accounting services.

Alqaraleh (2011) examined the impact of using information technology on the credibility of financial statements as perceived by the external auditors in Jordan.

To achieve the purpose of study, a questionnaire had been developed and distributed to the sample of the study which consists of 220 external auditors.

The results showed a statistical significant impact for using information technology and electronic disclosure risk on the credibility of financial statements from the point of view of the external auditors in Jordan.

\section{Theoretical Framework}

\section{External Audit}

External audit is considered as one of the most important processes contributing to the achievement of reliable accounting information, which produces accurate and reliable information through using controls tools for different activities in the organization (Youssef, 2013). 
The external audit is a:

Review of the financial statements of an organization by independent legal authorized auditors. The main objective of the external audit is to provide an opinion on the financial statements. The word audit originates from the Latin word (audire) to listen. The auditor is defined as a listener: one who reviews the statements (Jovanova \& Josheski, 2011, p. 2).

\section{The Importance of the Audit}

The importance of auditing is determined by providing service for multiple parties who used the audited financial statements in making decisions, and examples of these parties are as follows (Al-Bawab, 2012):

(1) Management: The auditor's report illustrates the impact of effective management, where it depends upon the development plans, monitoring and evaluation of the performance of the management;

(2) Investors: The auditors' report to investors represents a safety tool for their money, where the investors depend on the financial statements certified by an auditor who is independent and impartial when they think about making any decision related to their savings and their investments in order to gain the highest return possible;

(3) Lenders: In general, banks prefer to rely on financial statements audited when examining the financial centers of the projects that apply for credit facilities and loans from them;

(4) Government bodies: Based on the audited financial statements for many purposes, including planning, control and taxation, pricing, and the report of subsidies to some industries (Budur, 2008, p. 97).

Several studies have indicated that the credibility and fairness of the published financial statements of the companies depend on the existence of audit committees emanating from the boards of directors of these companies, where the audit committees increase the effectiveness of the supervision of the preparation of financial statements and reduce disputes between management and external auditor (Ahmed, 2011).

\section{The Role of External Auditor}

Kassem and Higson (2016) illustrated that the auditor's responsibility to detect and report misstatements resulting from illegal acts having a direct and material effect on the determination of financial statement amounts is the same as that for misstatements caused by error or fraud.

While Ojo (2006) showed that the role of the external auditor in the supervisory process requires standards such as independence, objectivity and integrity to be achieved.

If we compare the regulator and external auditor's performance, we can find that both of them have the same functions regarding the verification of financial statements, and they serve particular interests, where the regulator works towards safeguarding financial stability and investor interests, while the external auditor serves the private interests of the shareholders of a company.

\section{Information Technology and Audit}

International professional organizations were interested in providing the foundations and guidelines for auditing under information technology, especially the International Federation of Accountants (IFAC), which issued a set of standards and international audit data, some of which are directly related to the audit under information technology, such as International Review Statement No. 1009, ISA 401, and others indirectly include the subject of auditing the information technology, such as International Review Statement No. 1002 and 1008 and International Auditing Standard No. 402 (Al-Shantee, 2011).

Dowling (2009) illustrated that the auditor's participation in system design will be more sensitive and necessary in the case of advanced operating systems and contributes to the achievement of the following: 
(1) Ensure the discovery of anomalies and reduce the possibility of fraud and manipulation of the computer because of the possibility of developing better accounting control systems;

(2) The auditor will be able to use better methods to collect evidence and increase the likelihood of discovery of errors and fraud;

(3) Addressing problems related to loss of documentary evidence;

(4) Provide the auditor with copies of all programs related to important accounting applications and their amendments.

While Juma'a (2012) illustrated that the auditor cannot perform his/her task in auditing electronic accounting operations without using the computer because of the following reasons:

(1) Continuous development of audit functions and procedures as a result of the electronic operation of accounting data;

(2) Provide the time required to perform the audit process due to the impact of the audit on the financial position of many enterprises.

\section{Methodology}

In order to accomplish the purpose of the study, a questionnaire was made with 20 questions that measure and test the study hypotheses.

\section{Selection of the Sample}

The sample of this study consists of external auditors who worked in auditing offices in Jordan and obtained a license to practice the profession from the Jordan Association of Certified Public Accountants, and their number was 70 , whereas a questionnaire survey was designed and distributed to them. A total of 68 questionnaires were received that are valid for statistical analysis accounting for $97 \%$ of the overall distributed questionnaires.

\section{Statistical Techniques Used}

To analyze the collected data through using SPSS statistical software, we used the following tests:

(1) Reliability analysis;

(2) Descriptive analysis includes: frequencies, percent, mean and standard deviation;

(3) One sample $t$-test: to test the study hypotheses.

\section{Data Analyses}

\section{Reliability Analysis}

From Table 1, we note that the range of Cronbach's alpha was between 0.9182 and 0.6904 , and the value for all the questions was 0.8012 . In addition, these values indicate very good results, because it indicates a strong correlation between the questions.

Table 1

Reliability Analysis

\begin{tabular}{ll}
\hline Questions & Cronbach's alpha \\
\hline Using information technology to examine financial information & 0.6904 \\
Ensure the credibility of the financial statements & 0.9182 \\
Total questions & 0.8012 \\
\hline
\end{tabular}




\section{Descriptive Statistics of the Sample Members}

From Table 2, we can note the following:

Specialization: The results show that most of the members of the sample are of accounting specialization, accounting for $79.4 \%$, while the remaining sample (20.6\%) have finance specialization.

Qualification: Most of the members of the sample are of bachelor qualification, with $54.4 \%$, followed by individuals who have master qualification (35.3\%), and finally individuals with doctorate qualification (10.3\%).

Years of experience: The majority of the respondents (36.8\%) had experience of 1 to less than 5 years, followed by individuals (23.5\%) with experience of 15 years and more, and individuals with experience of 10 to less than 15 years, with $20.6 \%$. Finally, $19.1 \%$ of the sample members had experience of 5 to less than 10 years.

Table 2

Distribution of Sample Members According to Job Variables $(n=68)$

\begin{tabular}{llcc}
\hline Variable & Level & Frequency & Percent (\%) \\
\hline \multirow{2}{*}{ Specialization } & Accounting & 54 & 79.4 \\
& Finance & 14 & 20.6 \\
\hline Total & & 68 & 100.0 \\
\hline \multirow{2}{*}{ Qualification } & Bachelor & 37 & 54.4 \\
& Master & 24 & 35.3 \\
\hline Total & Doctorate & 7 & 10.3 \\
\hline & & 68 & 100.0 \\
Years of experience & 1 to less than 5 years & 25 & 36.8 \\
& 5 to less than 10 years & 13 & 19.1 \\
\hline Total & 10 to less than 15 years & 14 & 20.6 \\
\hline
\end{tabular}

Discussing the Study Questions

To discuss the study questions, we compute the mean and the standard deviation for the answers of sample's member, the five-level "questionnaire" study (Likert) was used as follows:

$1=$ Very disagree

$2=$ Disagree

$3=$ Neutral

$4=$ Agree

$5=$ Very agree

Depended on:

Mean of 1 to less than 2.33 refers to disagreement.

Mean of 2.33 to less than 3.66 refers to neutral.

Mean of 3.66 to 5 refers to agreement.

First dimension (Using information technology to examine financial information). From Table 3 below, we can note the following:

(1) The range of mean for the first dimension (using information technology to examine financial information) was directed towards neutral, where the lowest mean was 2.867 which refers to "the external auditor is interested in updating the company's electronic financial system", and this indicated neutral about this aspect, and the highest mean was 3.264 which refers to "the external auditor is keen to ensure the existence 
of procedures that ensure the periodic examination of documents and records by those responsible for this work in the company", indicating neutral about this aspect;

(2) The average of the mean was 3.086 and this indicated neutral about this dimension.

Table 3

Mean for Member Sample About the First Dimension $(n=68)$

\begin{tabular}{|c|c|c|}
\hline No. & Questions $\quad$ Mean & SD \\
\hline 1 & $\begin{array}{l}\text { The external auditor tests the information system, which must achieve the } 3.191 \\
\text { production process of information with high quality }\end{array}$ & 0.6748 \\
\hline 2 & $\begin{array}{l}\text { The external auditor examines the availability of the procedures related to } 3.147 \\
\text { the electronic information system protection against potential risks }\end{array}$ & 0.6292 \\
\hline 3 & $\begin{array}{l}\text { The external auditor checks the data protection procedures resulting from } 3.073 \\
\text { data operations by making backups that are continuously saved and updated }\end{array}$ & 0.7189 \\
\hline 4 & $\begin{array}{l}\text { The external auditor is keen to ensure that the company has policies to } 3.044 \\
\text { make use of the electronic information system and to ensure that it is used } \\
\text { and reviewed periodically }\end{array}$ & 0.7214 \\
\hline 5 & $\begin{array}{l}\text { The external auditor is keen to ensure that there are control procedures } 3.014 \\
\text { which ensure accuracy and consistency in the preparation of data } \\
\text { electronically }\end{array}$ & 0.6800 \\
\hline 6 & $\begin{array}{l}\text { The external auditor is keen to ensure the existence of procedures that } 3.176 \\
\text { ensure safety and reliability in the data operation }\end{array}$ & 0.7519 \\
\hline 7 & $\begin{array}{l}\text { The external auditor is keen to ensure the existence of procedures that } 3.264 \\
\text { ensure the periodic examination of documents and records by those } \\
\text { responsible for this work in the company }\end{array}$ & 0.7845 \\
\hline 8 & $\begin{array}{l}\text { The external auditor is keen to ensure that the company's information } 3.000 \\
\text { system is free of viruses }\end{array}$ & 0.8638 \\
\hline 9 & $\begin{array}{l}\text { The external auditor is interested in updating the company's electronic } 2.867 \\
\text { financial system }\end{array}$ & 0.9288 \\
\hline Avg. & 3.086 & 0.7504 \\
\hline
\end{tabular}

Table 4

Mean for Member Sample About the Second Dimension $(n=68)$

\begin{tabular}{|c|c|c|c|}
\hline No. & Questions & Mean & SD \\
\hline 10 & $\begin{array}{l}\text { The external auditor verifies the reliability of the data listed in the financial } \\
\text { statements before publication }\end{array}$ & 4.044 & 0.7810 \\
\hline 11 & $\begin{array}{l}\text { The external auditor verifies the credibility of the data listed in the financial } \\
\text { statements before submission to the beneficiaries }\end{array}$ & 3.882 & 0.9546 \\
\hline 12 & The external auditor supervises the publication of the financial statements & 4.147 & 0.8684 \\
\hline 13 & $\begin{array}{l}\text { The external auditor is keen to compare manually prepared financial data } \\
\text { with the financial data that published electronically }\end{array}$ & 4.279 & 0.6877 \\
\hline 14 & $\begin{array}{l}\text { The external auditor adopts the financial statements before publishing them } \\
\text { on the company's website }\end{array}$ & 4.014 & 0.9059 \\
\hline 15 & $\begin{array}{l}\text { The external auditor is keen to follow up the published data on the } \\
\text { company's website periodically }\end{array}$ & 4.044 & 0.8183 \\
\hline 16 & $\begin{array}{l}\text { The external auditor analyzes the statements and key accounts provided by } \\
\text { the company management }\end{array}$ & 4.044 & 0.7810 \\
\hline 17 & $\begin{array}{l}\text { The external auditor compares items in different periods and uses ratios to } \\
\text { link information }\end{array}$ & 4.044 & 0.7810 \\
\hline 18 & $\begin{array}{l}\text { The external auditor compares financial information with non-financial } \\
\text { information in the company }\end{array}$ & 3.661 & 1.0735 \\
\hline 19 & $\begin{array}{l}\text { The external auditor compares the estimated budgets with the actual } \\
\text { balance sheet in the company }\end{array}$ & 4.147 & 0.8684 \\
\hline 20 & $\begin{array}{l}\text { The external auditor relies on the auditing guide and international } \\
\text { accounting standards when checking }\end{array}$ & 4.279 & 0.6192 \\
\hline Avg. & & 4.0534 & 0.8308 \\
\hline
\end{tabular}


Second dimension (Ensure the credibility of the financial statements). From Table 4, we can note the following:

(1) The mean for the second dimension (ensure the credibility of the financial statements) was directed towards agreement, where the lowest mean was 3.661 which refers to "the external auditor compares financial information with non-financial information in the company", indicating agreement about this aspect, and the highest mean was 4.279 which refers to "the external auditor is keen to compare manually prepared financial data with the financial data that published electronically" and "the external auditor relies on the auditing guide and international accounting standards when checking", and this indicated agreement about these two aspects;

(2) The average of the mean was 4.0534 which indicates agreement about this dimension.

\section{Testing of Hypotheses}

To test the hypotheses, we use one sample $t$-test, and the results were as follows:

Ha1: The external auditor uses the information technology to examine the financial information listed in the financial statements.

Table 5

Results of One Sample T-Test for Using Information Technology to Examine Financial Information

\begin{tabular}{llll}
\hline Item & $t$-value & Mean & Sig. \\
\hline Using information technology to examine financial information & 14.513 & 3.8007 & 0.000 \\
\hline
\end{tabular}

From Table 5 above, we can note that the external auditor uses the information technology to examine the financial information listed in the financial statements, where the significant value was 0.000 , and this value is significant at $\alpha \leq 0.005$. So we reject the null hypothesis and accept the alternative hypothesis that says: The external auditor uses the information technology to examine the financial information listed in the financial statements.

Ha2: The external auditor is keen to ensure the credibility of the financial statements of the company.

Table 6

Results of One Sample T-Test for Ensuring the Credibility of the Financial Statements

\begin{tabular}{llll}
\hline Item & $t$-value & Mean & Sig. \\
\hline Ensure the credibility of the financial statements & 13.958 & 4.053 & 0.000 \\
\hline
\end{tabular}

From Table 6 above, we can note that the external auditor is keen to ensure the credibility of the financial statements of the company, where the significant value was 0.000 , and this value is significant at $\alpha \leq 0.005$. So we reject the null hypothesis and accept the alternative hypothesis that says: The external auditor is keen to ensure the credibility of the financial statements of the company.

This result is in accordance with Almeshal (2014) that found a positive significant role for the auditor independence in enhancing the creditability of accounting information.

\section{Conclusion}

This study aimed to examine the role of external auditor in protecting the financial information listed in the financial statements in the Jordanian industrial companies, and the results were as follows: 
The external auditor uses the information technology to examine the financial information listed in the financial statements, and the most important usage was to ensure the existence of procedures that ensure the periodic examination of documents and records by those responsible for this work in the company, with the highest mean of 3.264, while the lowest usage was the interest in updating the company's electronic financial system with the mean of 2.867 .

The external auditor is keen to ensure the credibility of the financial statements of the company, and the highest mean was for the item "compare manually prepared financial data with the financial data that published electronically" and "relies on the auditing guide and international accounting standards when checking", with the mean of 4.279, while the lowest mean was for "compare financial information with non-financial information in the company", with the mean of 3.661.

Based on study conclusions, the researcher recommends the following:

(1) The external auditor in the Jordanian industrial companies must be more interested in updating the company's electronic financial system;

(2) It is very important to ensure that the company has policies to make use of the electronic information system and to ensure that it is used and reviewed periodically;

(3) It is very important to provide training courses for the external auditors regarding how to use computerized systems and accounting programs in auditing;

(4) Apply this study in another economic sector, such as service sector and financial sector.

\section{References}

Ahmed, M., \& Shil, S. (2013). Protecting existing and prospective investors and the role of internal auditors. Independent Business Review, 6(2), 26-51.

Ahmed, S. (2011). The role of audit committee as a supportive tool of corporate governance on enhancing the quality of financial reports: An applied study on Egyptian pharmaceutical corporations. Jordanian Journal of Business Administration, 7(1), 43-66.

Alarbeed, E., Alothman, M., \& Assee, A. (2014). The role of governance rules in improving the auditor's ability to detect fraud in the financial statements: Field study on companies listed in the Syrian Securities Commission. Tishreen University Journal for Research and Scientific Studies -Economic and Legal Sciences Series, 36(5), 453-475.

Al-Bawab, A. (2012). The factors which affect on the choice of the external auditor in Jordanian banks from the perspective of the external auditor in Jordan (An empirical study). International Journal of Humanities and Social Science, 2(6), 180-192.

Almeshal, B. (2014). The role of auditor independence in achieving governance and its impact on accounting information reliability - Field study on audit firms in Palestine (Master thesis, Al-Azhar University, Gaza, Palestine).

Alqaraleh, M. (2011). The impact of using information technology on the credibility of financial statements as perceived by the external Jordanian auditors (Master thesis, Middle East University, Jordan).

Al-Shantee, A. (2011). The role of information technology in the development of auditing profession: An empirical study on audit offices in the Hashemite Kingdom of Jordan. Journal of Baghdad College of Economic Sciences, 27, 345-374.

Budur, J. I. (2008). Factors affecting the external auditor's fees in the Hashemite Kingdom of Jordan. Arab Journal of Accounting, 11(1), University of Bahrain, Kingdom of Bahrain.

DiGabriele, J. A., \& Ojo, M. (2014). Objectivity and independence: The dual roles of external auditors. Journal of Forensic \& Investigative Accounting, 6(2), 200-224.

Dowling, C. (2009). Appropriate audit support system use: The influence of auditor, audit team, and firm factors. The Accounting Review, 3(84), 770-802.

Jovanova, B., \& Josheski, D. (2011). External audit and relationship between internal auditors, supervisory body and external auditors of banking sector in the Republic of Macedonia. Retrieved from http://ssrn.com/abstract=2080498

Jovković, B., Ljubisavljević, S., \& Obradović, V. (2012). Empirical research on the external audit of banks in Serbia. Economic Annals, 57(194), 41-62. 
Juma'a, A. (2012). Introduction to auditing and assurance in accordance with International Standards on Auditing (1st ed.). Dar Safa for Publishing and Distribution, Amman, Jordan.

Kassem, R., \& Higson, A. W. (2016). External auditors and corporate corruption: Implications for external audit regulators. Current Issues in Auditing, 10(1), 1-10.

Kasswna, R. (2012). The impact of information technology on external audit fees - A field study in the Hashemite Kingdom of Jordan. European Journal of Business and Management, 4(14), 92-102.

Lotfii, A. (2005). Different auditing for different purposes. Aldar Aljameeyah, Cairo, Egypt.

Matar, S. (2012). The impact of legal responsibility of external auditors on auditing quality and investment level (A thesis submitted for the degree of Doctor of Philosophy, Brunel University).

Ojo, M. (2006). The role of external auditors and international accounting bodies in financial regulation and supervision. Munich Personal RePEc Archive (MPRA), Paper No. 354, pp. 1-14.

Salem, M. (2012). An overview of research on auditor's responsibility to detect fraud on financial statements. The Journal of Global Business Management, 8(2), 218-229.

Tawfeq, R., \& Jabali, M. (2014). The relationship between the information systems of accounting, auditing, and how to provide reliable information to characterize the service auditor. Global Journal of Commerce and Management Perspective, 3(2), 95-101.

Youssef, M. (2013). The effectiveness of external audit in achieving the reliability of accounting information under the financial accounting system (SCF) (Master thesis, Qasidi Merbah University, Ouargla, Algeria).

Zghoot, M. (2016). The effectiveness of using information technology (IT) in auditing and its impact on improving the quality of auditing service in the Gaza Strip: A field study on auditing companies operating in the Gaza Strip (Master thesis, Islamic University, Gaza, Palestine). 